\title{
Pragmatic dimensions in parable research and the divine economy of the basileia
}

\begin{abstract}
Author:
Andries G. van Aarde ${ }^{1}$

Affiliation:

${ }^{1}$ Department of New

Testament Studies, Faculty

of Theology, University of

Pretoria, South Africa

Note:

This article was a paper presented at a pane discussion on 'Parables and religious knowledge' during the EASR Conference 'Religion and pluralities of knowledge' at the University of Groningen, the Netherlands, 11-14 May 2014. The project is located at Utrecht University and the School of Catholic Theology at the Tilburg University and is directed by Prof. Dr Eric Ottenheijm, Prof. Dr Marcel Poorthuis and Prof. Dr

Annette Merz. Andries G. van Aarde is honorary professor and senior research fellow in the Centre for the Advancement of Scholarship at the University of Pretoria, South Africa.
\end{abstract}

Correspondence to:

Andries van Aarde

Email:

andries.vanaarde@up.ac.za

Postal address:

Private Bag X20, Hatfield

0028, South Africa

Dates:

Received: 15 Apr. 2014

Accepted: 07 June 2014

Published: 14 Oct. 2014

How to cite this article: Van Aarde, A.G., 2014, 'Pragmatic dimensions in parable research and the divine economy of the basileia', HTS Teologiese Studies/Theological Studies 70(1), Art. \#2688, 11 pages. http://dx.doi. org/10.4102/hts.v70i1.2688

\section{Read online:}

Interpreting a parable requires the decoding of the nature of an analogy which will reveal the degree of the deciphering of the riddle communicated through parabolic discourse. In biblical hermeneutics throughout the 20th century Aristotelian logic revived in parable research in that the nature of a 'meta-phor' between the subject and the predicate in a comparison (the so-called Ähnlichkeitsrelation) was understood in terms of either 'epi-phor' (analogy) or 'dia-phor' (disanalogy). This distinction contributes to the disclosure of power relationships concealed in religious discourse by uncovering the subversive dimension of parabolic discourse. This article focuses on aspects from pragmatic linguistics (especially the role of implicature in communication) and antisociety language usage. These two aspects are explained by illustrations from the Jesus tradition (parable of the pearl), Epictetus's dissertations (meal parable), and Paul's comments on marriage (1 Cor 7).

\section{Introduction}

In Stoic philosophy, at the turn of the pre- and 1st century Christian eras, the notion 'divine economy', in Greek dioikēsis theia (see Brent Shaw 1985:29), that is a 'divine administration' (Liddell \& Scott [1843] 1961:432), signifies a parabolic speech act which expresses one of the greatest epistemological transformations in history. ${ }^{1}$ It concurred with and even prepared the contextualisation of Jesus' kingdom ethics, brought about by the earliest Christ followers. In the past there were scholars who thought that Christianity earns the merit for this transformation (cf., inter alia, Ernst Troeltsch [1912] 1992:66-67). However, this is not the case. The merit belongs to Stoic metaphysics, logic and ethics, specifically advocated by the physically disabled Epictetus from Hierapolis in Phrygia (cf. Anthony Long 2002:8), 'a slave woman's son' and for many years himself the slave of Epaphroditus, the 'freedman and administrative secretary of Nero' (William Oldfather [1925] 1998:vii-viii).

This article focuses on Epictetus's dissertations in order to understand the kind of parabolic discourse which is articulated from a Stoic epistemological, metaphysical and ethical perspective, representing an ideology which is transformative in contextual effect. ${ }^{2}$ The argument posed is that identifying the pragmatic dimensions in parable research provides cues to explain the notion 'divine economy' of a basileia. It was the 'kingdom-speech act' which influenced the authors of New Testament writings and early Christian literature immensely. In the same vein the Stoics created a transformation in words and deeds which can be seen as a profound epistemological shift. Epictetus's legitimatisation of suicide and Paul's emphasis on participatory death serve as examples of such Stoic and anti-Stoic parabolic speech act, denoting an epistemological shift. In the article the shift is illustrated by examples from Epictetus's dissertations (meal parable), Paul's comments on marriage (1 Cor 7), and the Jesus tradition (parable of the pearl). Paul's view on marriage is also expressed in an analogical (metaphorical) way. These examples represent a speech act conveying an ethos which is a product of the Stoic notion of the divine economy of the basileia.

\section{Basileia versus polis}

The metaphor 'divine economy' symbolises a situational and contextual change with subsequent existential consequences that caused transformation in people's ethos and their ethical outlook on metaphysical and physical relations. It represents, in Monroe Beardsley's (1958:138) words, a 'metaphorical twist' in the sense that the hegemony of the previous paradigm of the polis

1.John Sellars (2003:6) describes Epictetus's philosophy 'as an art of living, as an activity directed toward the transformation of one's way of life (bios). In contrast to the conception of philosophy as logos, the conception is explicitly concerned with the way in which one lives. The function of philosophy, for Epictetus, is to transform one's behaviour, and any development in genuine philosophical understanding will, for him, always be expressed in one's actions (erga).'

2.Outside the religious domain a similar attempt is to be found in Richard Brown's (1976:169-197) work in which he endorses an epistemology of metaphor which he calls 'cognitive aesthetics' and 'symbolic realism'.

Copyright: (c) 2014. The Authors. Licensee: AOSIS OpenJournals. This work is licensed under the Creative Commons Attribution License. 
state became deconstructed. The brutality of an exclusive domination with particularistically inclined nepotism and exploitation of outsiders was displaced with the concept basileia over against polis. Epictetus still uses the term polis, for example as the translation of the Latin res publica, meaning 'societal affairs' (Shaw 1985:29). However, he (Discourses $1.23 ; 4.11$ ) uses this concept in a radically different way than Aristoteles's (Politica 1253a) who regards a human being as 'by nature a political being' who exists in terms of the polis:

For why do you call yourself an Athenian instead of saying merely that it was that corner into which your paltry body was cast at birth? ... Anyone who has contemplated the divine economy (dioikessis tou kosmou) and who has learnt that the greatest, most authoritative, and most comprehensive of all things is the system of man and god (to systema to ex anthropou kai theou) ... why should not such a man and god call himself 'cosmic (kosmios)'? (Epictetus Discourses 1.9.3-6; cited \& transl. Brent Shaw 1985:29)

In God's oikeiōsis humankind does not rule in terms of a selfish hierarchical ideology. ${ }^{3}$ The word oikeiōsis has the potential referential meaning of 'affinity' and 'affection', and the word oikeotēs can refer to 'friendship' and 'intimacy' (Liddell \& Scott [1843] 1961:1202). The concept 'economy' is comparable to the term 'administration' (dioikēsis). The concept basileia is frequently used as its equivalent in the so-called Diogenes Laertius ([1853] 2008) which consists of anecdotes by Stoic philosophers such as Persaios (Diog. Laert. 7.36), Kleanthes (Diog. Laert. 7.175), and Sphairos (Diog. Laert. 7.178) (cf. Malitz 1988:161, n. 72; Shaw 1985:28, n. 23). In the basileia, referring to the realm where God rules the oikeiosis (= dioikēsis theia), people are no longer exclusively defined by citizenship or membership bound to a polis state. The nomos and phusis of the 'divine economy' is that the basileia is 'co-extensive with all [hu]mankind' (Baldry 1965:151-166, 177-194). According to Epictetus (Discourses 1.23.1), this 'norm' and this 'nature', metaphorically seen, represent a kind of covering (he kalupsis), in the sense of protection and care-a husk which forms the outer pod covering seed or fruit. In the 'divine economy' nobody is dominated, exploited or marginalised. In the basileia, reigned in terms of the dogmata according to 'divine nature', humankind 'is once and for all set in a framework' (hapax en tō kalupsei theis) of mutual care. Shaw (1985) summarises the essence of Epictetus's vision on such a 'divine economy' as follows (emphasis and gender exclusive formulation original):

To Epictetus the essence of the whole new order in which man is to be situated in short, the very essence of Stoicism itself, was encapsulated in his summation: 'The divine economy ....' [Epictetus] further specifies the superimposed layers of social roles that constitute the hierarchy of the Divine Economy. In one of his most explicit statements [Discourses, 1.10; 2.10], he claims that every man has a 'cosmic' vocation, namely that of being a human (epangelion anthropou) but that this grande profession is composed of a subordinate subset of vocations [an overarching order of things in which 'all men are brothers']. One is:

3.Jürgen Malitz (1988:156) puts it as follows: "In diesem Sinne war die stoische Philosophie zur Zeit der Republik alles andere als eine Bedrohung der bestehende Machtverhältnisse.' (cf. also Wistrand 1979:93-101; Millar 1965:141-148).
1. a human being (to proton anthropos)

2. a citizen of the world (polites tou kosmou)

3. an active, not just a passive or servile, part of the world

4. one who can comprehend the divine economy (dioikesis theia)

5. one who has the vocation of citizen of a state (epangelion politou)

6. one who shares given genetic roles (e.g. son, brother) and given social roles (e.g. town councilor, soldier). (Shaw 1985:29-30)

His Stoic vision is ethically universal in outlook with an inclusive propensity and an ethos conducive for a social cohesion never known before (cf. David Konstan 2010:233-248). William Oldfather ([1925] 1998; gender exclusivity original) describes this vision as follows:

Among duties [Epictetus] is concerned principally with those of social character. Nature places us in certain relations to other persons, and these determine our obligations to parents, brothers, children, kinsmen, friends, fellow-citizens and mankind in general. We ought to have the sense of fellowship and partnership (koinonikoi), that is, in thought and in action we ought to remember the social organization in which we have been placed by the divine order. The shortcomings of our fellowmen are to be met with patience and charity, and we should not allow ourselves to grow indignant over them, for they are a necessary element in the universal plan. (p. xxiii)

In other words, in the divine basileia those social roles which were considered previously to be effectively outside the polis, are part of the moral duty of humankind which is called to live in accordance with Nature (in Greek philosophy, often referring to God) (see Shaw 1985:35). These les misérables are the 'extremely poor, slaves, defeated political subjects, and women' (cf. Hands 1968:70-72). Inclusivity presumes the acknowledgement of dignity and to be free of any other person, except free of God's natural order. It is thus not a surprise that words related to personal freedom appear in Epictetus's discourses six times more than in the New Testament, namely 130 times, and twice more than Epictetus's interpreter, the Emperor Marcus Aurelius (Eduard Zeller 1909:776; cf. Oldfather [1925] 1998:xvii). Geert Roskam (2005:110) says: '[for Epictetus] freedom consists in wishing what actually happens ... having the possibility to choose what is ....'

Epictetus became attached to Stoic philosophy when he was a slave in Emperor Nero's household and became a student of Musonius Rufus (c. 30-100 CE) (Cynthia King [2010] 2011), one of the great Stoics. After he attained his freedom he founded his own school of philosophy in Nicopolis in Epirus, opposite Actium (Oldfather [1925] 1998:x-xi). Like Socrates and Jesus of Nazareth he never wrote himself. In circa $108 \mathrm{CE}$, Epictetus's student Flavius Arrianus (see Philip A. Stadter 1967) put his mentor's narrative-like aphoristic and metaphorical teachings in a collection of eight discourses (of which four survived), some fragments and a compendium, the Encheiridion (Manual). His radical inclusivity was memorised as sayables expressed in assertibles, including parabolic discourse which was based on Aristoteles's heritage. 


\section{Aristotelian heritage}

Notwithstanding Jacques Derrida's ([1972] 1982b:178, 280, 1982a:23-26, 1978:5-33) critique against the logocentric way of Aristotelian thinking, ${ }^{4}$ Aristoteles's (384-322) definition of metaphor forms the basis for a reflection on the relationship between 'metaphor' and 'discourse'. In his Poetics (1457b.6-9) Aristoteles defines metaphor as follows:

Metaphor consists in giving the thing a name that belongs to somebody else; the transference being either from genus to species to genus, or from species to species, or on grounds of analogy.

Paul Gordon (1990:85), referring to Fyfe's ([1953] 1973:81) translation of the Poetics, explains Aristoteles's definition simply: 'Metaphor is the introduction (epiphora) of a word which belongs to something else (onomatos allotrios)' (Poetics xxi.7). In Paul Ricoeur's (1974) mind:

the metaphor [defined] by Aristoteles - as a transposition of an alien name (or word) (onoma) - is not cancelled by a theory which lays the stress on the contextual action which creates the shift of meaning in the word. (p. 96)

The expression 'contextual action' assumes situation and discourse.

It is clear that the essence of a 'metaphor' is the principle of analogy, ana-logia, that is comparison. In parable research the German terms Ähnlichkeitsrelation (comparison/similarity) and Anschaulichkeit (similarity/comparison) were used since the work of Adolf Jülicher (1888) to express the kind of analogia between two lekta. ${ }^{5}$ This relationship encloses elements with similar traits to such an extent that they are comparable. Scholarly elaboration on Jülicher's (1888:24-121) reflection on the 'Wesen der Gleichnisreden' has produced a typology of several categories among which 'metaphor' is only one of these multiple forms. The others are proverb, simile, similitude, and parable (Charles Hedrick 2004:6-9; Andries Van Aarde 1994:231-235). In his 2012 publication The power of parable: How fiction by Jesus became fiction about Jesus, Dominic Crossan $(2012: 10,95,134)$ distinguishes a three-fold typology of Jesus' parabolic teaching style: 'riddle parables; 'example parables', and 'challenge parables'. In 1992 he categorised the Jesus parabolic discourse as aphoristic parables, extended parables, and narrative parables (Dominic Crossan

\footnotetext{
4.Similar to Paul Ricoeur's disposition of a 'reanimation of dead metaphor' (see later) one should simultaneously acknowledge and criticize Jacques Derrida (1982a:26) who is perceptive of the ambiguity in the pharmakeia of metaphysics that 'can neither kill nor cure', and therefore his 'attention to the profound ambiguities of language' so that we could find ourselves in a 'state of noncommitted polymorphous language' so that we could find ourselves in a 'state of noncommitted polymorphous exploration': 'Thus we have virtual metaphors of metaphors, traces of traces,
repeating themselves ad infinitum, ad nauseam, in divergent, discordant variations on a theme' (Jacques Derrida 1982a:23-24).

5.In the history of Stoic grammar and logic the term lekton refers to a kind of 'proposition' (see Blank \& Atherton 2003:323) and forms a 'part of a speech" (mere tou logou) (Blank \& Atherton 2003:114). The term 'logos' constitutes a 'word-complex' and is distinguishable from lekton which refers to a sayable that can include, amongst others, an assertible, an inquiry, an imperatival, a question, et cetera (see Bobzien 2003:85-86). Assertibles 'can be stated, but they are not themselves stabien ' (B.85-86). Assertibles 'can be stated, but they are not themselves statements' (Bobzien 2003:86). 'Statability' presumes a truth-value' (Bobzien 2003:87). Truth and falsehood are temporal properties of assertibles: 'Thi "temporality" of the [truth-values of] assertibles has a number of consequences for Stoic logic. In particular, assertibles can in principle change their truth-value: the assertible "It is day" is true now, false later, and true again tomorrow. The Stoics called assertibles that (can) change their truth-value "changing assertibles" (metapiptonta). Most Stoic examples belong to this kind' (Bobzien 2003:87-88).
}

1992:148-150). Aphorism, according to Hedrick (2004:8), refers to non-referential community wisdom. ${ }^{6}$ In this article my attention is not only on the parabolic discourse in the Jesus tradition, but more specifically on 'metaphor' and 'community wisdom', inspired by Stoic philosophy and applied by a 'Christ-follower' such as Paul who ascribes to himself the social roles of being a slave and an apostle in the 'divine economy', granted by God.

In Paul Ricoeur's [1986] 2004 collection of essays on the 'rule of metaphor', Vianney Décarie ([1975] [2003] 2004) describes some distinctive elements in Aristoteles's use: The first is that the concept 'metaphor' is not connected to discourse, but to a single word (Vianney Décarie ([1975] [2003] 2004:17). However, because there exists in Aristoteles's understanding 'two seemingly contrasting moments' (the interaction between 'tenor' and 'vehicle') (Vianney Décarie ([1975] [2003] 2004:38), metaphor helps to 'make discourse appear to the senses.'

To follow Aristoteles on this requires an insight into his understanding of the relationship between metaphor and discourse: foremost, the 'epiphora' of a noun presupposes movement, that is displacement 'from ... to ...'. The consequence of such a 'movement' is that 'metaphor is a borrowing' (Vianney Décarie [1975] [2003] 2004:18). Moving away from a word's proper meaning (i.e. the 'marked meaning') metaphor opposes, in other words, it displaces the proper meaning. This is done by endowing it with a different meaning. Epiferein is to carry over. The 'transposition' of a name (allotrios) is therefore a distinctive element of metaphor (Poetics 1457b.7). Metaphor implies deviation from the standard meaning (para to kurion - Poetics 1458a.23) to a name that belongs to 'something else' (para to eiōthos - Poetics 1458b.3) (Vianney Décarie [1975] [2003] 2004:19). Such an 'alien' usage is 'represented by the idea of substitution’ (Vianney Décarie [1975] [2003] 2004:20).

There was a time when scholars (e.g. Jülicher with regard to 'allegory') inferred from this insight the conclusion that metaphor does not carry new information. Because no new knowledge is communicated, metaphor has only an ornamental, decorative value (cf. Vianney Décarie [1975] [2003] 2004:21). However, Aristoteles's (Poetics 1457b.12-20) idea of 'transposition' operates - in terms of Sigmund Freud's theory of Das Unheimliche ([1919] 1970) between the oppositional structures of 'familiar' (oikeia) and 'foreign' (xenē). Paul Gordon (1990) formulates it this way:

Metaphor is thus 'uncanny' in the strict Freudian sense (Freud 1973), because it is foreign and so 'not of the house' (unheimlich), as well as being familiar and 'of the house' (heimlich). (p. 88; cf. Stefanie Groß 2005)

6.The expression 'non-referential' does not rule out either figurative significance or metaphor. The expression 'non-referential' denotes the insight that an aphorism refers to a more universally sapiental 'condition', rather than to a more particular 'condition' in a specific context.

7.Stefanie Groß (2005) explains the 'etymology' of the word 'unheimlich' by emphasising the positive meaning of 'heimlich a' in terms of the trust, security and delight which the concept 'house' provides, but simultaneously the 'house' obtains delight which the concept 'house' provides, but simultaneously the 'house' obtains
a negative meaning ('heimlich b') because it is a place to hide and to be discreet, and therefore 'unheimlich'. 
In the structure of language it 'involves a kind of mistake' (Vianney Décarie [1975] [2003] 2004:22), a 'true falsehood' (Paul Gordon 1990:86), a 'native foreignness' (Sigmund Freud ([1919] 1970:241-275), a 'logical absurdity' (Monroe Beardsley 1958:138), a 'clash between literal meanings within the same context' (Paul Ricoeur 1974:102), an assertion of similarity, as well as difference between two thoughts which 'are held in permanent tension with one another and are product of a new reality' (Sallie McFague 1982:37-38).

Because of this 'calculated error', metaphor is essentially a discursive phenomenon. ${ }^{8}$ This statement has an important consequence: 'because to metaphorize well is to see resemblance' (Décarie [1975] [2003] 2004:26). In Vianney Décarie's words: 'This brings us very close to our most extreme hypothesis. That is that the "metaphoric" that transgresses the categorical order also begets it.' According to Décarrie ([1975] [2003] 2004:38), this feature brings us to the 'heart of the problem of lexis [diction], whose function, we said, is to "make discourse appear to the senses".'

In other words, to understand that displacement of meaning through metaphor creates new meaning is to understand why the focus shifts from ornamental lexis to discursively communicative lexis. New meaning is established in a discourse on account of the important role of the created resemblance between the so-called opposing logical poles in language usage. This insight results in a definition such as (Johnson 1981:4): 'A metaphor is an elliptical simile useful for stylistic, rhetorical, and didactic purposes, but which can be translated into a literal paraphrase without any loss of cognitive content.'

Aristoteles's notion of 'resemblance' highlights similaritybased comparison. Substitution of meaning creates something else, something new. Ivor Armstrong Richards (1893-1979) infers from Aristoteles's use of metaphor the notion interaction (Richards ([1936] 1981:51). Richards is often referred to as the 'father of New Criticism' because he unprecedentedly started to interpret a text in and of itself without necessarily investigating its historical evolution and authorial intention. His notion of 'interaction' leads to the viewpoint that human thought is in essence metaphorical by nature. Human beings communicate with each other because they are thinking of things in terms of other things - moreover, and hopefully, in terms of 'the Other' in a non-reified sense. Axel Hübler (2011) quotes from George Lakoff's and Mark Johnson's (1980) work:

$[M]$ etaphor is pervasive in everyday life, not just in language but in thought and action. Our ordinary conceptual system, in terms of which we both think and act, is fundamentally metaphorical in nature. (p. 121)

One aspect of Aristoteles's work which we have left behind - ironically, because of the consequences of Aristoteles's

8.With the expression 'discursive phenomenon', that is collectively seen as 'discourse' I have something similar in mind when Aristoteles (Poetics xxii.16) considered 'lexis' as central to the fabric of a discourse (e.g. tragedy), consisting of the elements as central to the fabric of a discourse (e.g. tragedy), consisting of the elements
of seeing (opsis), singing (melos), saying (lexis), thinking (dianoia), characterising of seeing (opsis), singing (melos), saying (lexis), thinking (dia
(ethos), and intriguing (muthos = plot) (see Gordon 1990:84). thinking - is our insight that thinking of metaphor only in terms of single words should be replaced by thinking of rhetoric in terms of contexts and discourse that are essentially metaphorical because of the semantic relatedness of one word to another and the intertextual nature of discourse. The two related poles in epiphora is the interaction between 'tenor' and 'vehicle'.

Ensuing from the insight that metaphor is the borrowing of attributes from a particular word to displace the marked meaning of another word by means of creating a kind of similarity, the 'tenor' is the subject to which attributes are assigned and 'the vehicle' is the object whose attributes are borrowed. For example, a meal is the vehicle to ascribe characteristics to a social gathering such as a religious community. According to Max Black (1981:30-46), a metaphor therefore not only asserts similarities, but more often creates similarities between things. He distinguishes between the notions substitution, comparison and interaction views. In terms of substitution, 'A' simultaneously moves away and resemblances ' $\mathrm{B}$ ' in a metaphor, but ' $\mathrm{B}$ ' can also simply be substituted by ' $C$ ', which represents the literal equivalent of ' $\mathrm{B}$ ', for example 'the faith community is like a meal' and therefore community is a 'celebratory event'.

This has led to the interactive view of metaphors. Black (1981) describes this view as follows:

In the simplest formulation, when we use a metaphor we have two thoughts of different things together and supported by a single word, or phrase, whose meaning is a resultant of their interaction. (p. 38)

In other words, the meaning of the metaphor lies neither in ' $\mathrm{A}$ ' (tenor) nor in ' $\mathrm{B}$ ' (vehicle) but it is created by the juxtaposition of ' $A$ ' and ' $B$ ', which is metaphorically openended to create other juxtapositions. Contrary to the traditional view of a literal substitution, or a comparison theory based on the properties of the tenor (principal subject) and vehicle (subsidiary object), Black (1981:40) emphasises that the interaction between tenor and vehicle occurs on the basis of associated commonplaces. The latter refers to those attributes that are commonly believed to be the characteristic of an object, a person, or an event. This process pertains to both analogies (epiphora) and disanalogies (diaphora) (see Peter Wheelwright ([1962] 1973:72). The word epiphor is taken from Aristoteles's notion of 'transference' of a name to some other object. The idea on 'movement' is expressed by phora and 'over on to' by epi. An epiphor expresses a similarity. On the other hand, in the diaphor the 'movement' is 'through', that is dia. A diaphor does not express similarity or resemblance, but the juxtaposition of tenor and vehicle is rather paradoxical by nature.

Seen from this perspective, Paul Ricoeur (1981:228-247) emphasises the notions 'imagination' and 'feeling' to articulate the metaphorical process in poetry and rhetoric. According to Ricoeur (1981:233) the metaphor is in essence pictorial which inspires association of images that have 
previously been regarded as unassociated systems of syntheses:

Imagination ... is the ability to produce new kinds by assimilation and to produce them not above the differences, as in the concept, but in spite of and through the differences. (pp. 234)

To understand the process of metaphorical interaction one does not only 'see' but also 'feel' something (Ricoeur 1981:243).

Schleiermacher helped us not to confuse 'emotion' with 'feeling'. In the late-Romantic version of Affektenlehre a distinction was made between the concepts 'emotion' (Erfahrung) and 'feeling' (Gefühl). Schleiermacher built on Johann Gottfried von Herder's (1744-1803) ideas on language, hermeneutics, translation, the mind, art and aesthetics and religion (Herder [2006] 2009:29; cf. Betti [1962] 1990:177-188). For Schleiermacher ([1830] [1928] 1976:16-17) 'emotion' is the response to objects, to that which is finite, whereas 'feeling' is about being aware of one's own finitude (cf. Grondin 1994:71). Dependence on the Transcendent implies involvement, a feeling which Ricoeur (1981:243) calls 'self-assimilation', which in turn is a result of the illocutionary force of the metaphor as a discursive speech act. Such a discourse embodies a religious reality articulated by a metaphorical story or narrative. Such a speech act represents analogy (epi-phor) but often also disanalogy (dia-phor) which presupposes a 'tension of metaphor' (cf. Ricoeur 1975:95-96).

This means that the relationship between tenor and vehicle in a metaphor could confirm a view of reality endorsing the conventional view (epiphor), or it may challenge or subvert the conventional view of reality (diaphor). In other words, in a metaphor certain entities, either similar (epiphor) or dissimilar (diaphor), are juxtaposed in an interactive process by means of which new meaning is created. According to Robert Funk (1966:138), a parable of Jesus redirects attention by means of an 'imaginative shock'.

In parable research it is almost trivial to recur that Jesus' parabolic discourses express an alternative to a conventionally ordered society. However, it is not so inconsequential to reflect on Jesus' reordering of socio-ethical values, often expressed in metaphor, from (1) an antisociety language perspective (see Van Aarde 2009) and from (2) a perspective which I call the pragmatic dimension (see Van Aarde in press) in parable research. The latter relates to the notion 'implicature' as it is applied in pragmatic linguistics, inferred from Ludwig Wittgenstein's ([1918] [1922] 2010 Tractatus 7.1, cited by Wells [1954] 1961:269-283) insight that the practice of language is more important than its meaning. In Ricoeur's (1974) terms:

what is said of the subject is one thing; what I 'do' in saying that is another thing: I may make a mere description, or give an order, or formulate a wish, or give a warning, etc. (pp. 97-98)

According to Ricoeur (1974:100), ‘[o]nly genuine metaphors are at the same time "event" and "meaning".'
With the expression 'event' Ricoeur refers to the creation of a new world on account of a hermeneutical circularity between text and reader which causes a fusion of horizons (Horizontverschmelzung). ${ }^{9}$ In The rule of metaphor he puts it as follows: '[Only] the metaphorical twist is at once an event and a meaning, an event that means or signifies an emergent meaning created by language' (Ricoeur [1986] 2004:114; emphasis original). David Kaplan (2003) explains this pragmatic dimension of metaphor as follows (cf. Nikola Kompa \& Georg Meggle 2011:214):

The problem of metaphor is to describe and explain how creative and imaginative uses of language refer to reality in such a way that it produces new interpretations of the world. In The Rule of Metaphor Ricoeur develops his thesis that the split-reference of creative discourse [i.e. the reader's situation and the author's situation] discloses a possible way of being-in-the world that remains hidden from ordinary language and firstorder reference. The world of the work that unfolds in reading opens up nonsituational references revealing new possibilities of existence. A metaphor is a 'heuristic fiction' that 'redescribes' reality by referring to it in terms of something imaginative or fictional, allowing us to learn something about reality from fiction. Heuristic fiction helps us to perceive new relations and new connections among things, broadening our ability to express ourselves, interpret ourselves, and transform ourselves. (p. 48)

\section{Pragmatic dimensions}

Mary McGinn (1989:85-86) explains Wittgenstein's intention by emphasising that:

[the] fundamental point is not that speakers mean (or often mean) something other than what their words mean but that understanding [intelligibility] what a speaker means on a particular occasion requires more than recognizing what his words mean, in the first sense of 'mean'. (pp. 85-86)

To understand requires the understanding of the point of a speaker's act of assertion. It demands insight into the interests and motives behind an utterance (McGinn 1989:83-84). This leads to pragmatics which 'deals with meaning-in-context' (Wolfram Bublitz \& Neal R. Norrick 2011:4). In other words, pragmatics is concerned with the implicature of expressions, rather than with their lexicographic meaning alone (see, inter alia, Yan Huang 2011:397-424).

Peter Auer (1996:18-19) describes pragmatics as 'situationspecific common background knowledge.' It has to do with that which is being said between the lines, that which is created or omitted by language users through conscious or unconscious gaps. Jeffrey T. Reed (1997) puts it as follows:

Essentially, what this implies is that language comes to life only when functioning in some environment ... The 'context of situation' does not refer to all the bits and pieces of the material environment ... It refers to those features which are relevant to the speech that is taking place ... Pragmatics concerns itself with the reason why a statement is made, that which is implied or could possibly be implied by a statement, the act that is associated with it, and the effect achieved by the statement. (pp. 189-218)

9.'Beyond my situation as reader, beyond the author's situation, I offer myself to the possible ways of being-in-the-world which the text opens up and discovers for me (Ricoeur 1974:106). 
The 'reason why a statement is made' in a parabolic discourse is semiotically (= pragmatically) approached by Kristina Dronsch (2008:570-578) in terms of a hermeneutical model which she calls 'semiotisch-kulturwissenschaftlicher Ansatz zur Bestimmung der Bedeutung der Gleichnisse.' According to Dronsch (2008:580), such an approach has the consequence that one should depart from a 'jesuszentrierter Forschung der Gleichnisse' and 'das daraus resultierende Wahrheitskonzept, das sich an der historischen Referenz andockt.' This view offers an important challenge for reconsidering the pragmatical implicature of the use of the metaphor basileia in the Jesus tradition.

Pragmatics concerns itself with delexicalizing. It is not bound by the convention of the logic of phonologic, syntactical or semantic regularities in terms of which meaning is defined linguistically, but rather focuses on those codes that proffer an indication of how notions (concepts) manifest in language, and how a user of language could, by listening or reading, infer notions (concepts) from certain words. Put differently, pragmatics aims to infer the truth conditions of the contents of what a language user believes.

Paul Ricoeur ([1986] 2004:291) regards his 'new production of metaphor' (Morny Joy 1988:520) - arguing against Jacques Derrida's disposition (see remarks above) - the 'reanimation of dead metaphor' as an 'operation of de-lexicalizing' - an operation that 'has implications for reality' (Joy 1988:521). Morny Joy (1988) puts it as follows:

The final product of the ultimate form of referentiality of all texts as being that of human action is dependent on a reformulation of Aristotle's category of mimesis. Ricoeur links mimesis (as refiguration) to the heuristic intent of novel metaphor, framing both under the rubric of 'redescribing reality.' In this way, Ricoeur prevents representation from being identified with simple initiation or repetition, an attribution made by Derrida. Yet Ricoeur also wishes to push mimesis beyond mere tension or discord between descriptions of given and possible worldviews. His aim is to incorporate, beyond the boundaries of the 'is/is not' conflict, a dynamic understanding of being ... Consequently it now appears that the entire operation is to be played out against the backdrop of Being as Act, where Act (energeia) is the 'stuff' (phusis) of human nature and phronessis the judicious assessment of the appropriate incorporation of a new activity into existent modes of behaviour ... Ricoeur's designs in this manner have not yet been fully realized, and much care and discrimination will be needed to portray this vision in full. (pp. 522-523)

My vision on the pragmatic dimension of metaphor in the context of antisociety language is an attempt to take one step further in the process of such a realisation of 'being-asact' embedded in a world filled with paradoxical realities particularly in the religious domain. By doing so I understand the pragmatically dialectical 'event-meaning' in the creation of a 'fusion of horizons' ( i.e. the 'new world' of a reader) on account of a 'metaphorical twist' in an assertible statement as equivalent to an operation of delexicalization by means of relexicalisation and overlexicalisation. What this implies is that the marked meaning of a word (para to kurion) is displaced by a name that belongs to 'something else' (para to eiōthos):
Metaphor is the introduction (epiphora) of a word which belongs to something else (onomatos allotrios) (Aristoteles Poetics xxi.7). We have seen that in Stoic philosophy such a metaphorical twist created an epistemological transformation with ontological and ethical effect. The transformative dynamics of antisociety language provides a pragmaticlinguistic lens from which one can explain this paradigm shift in parabolic discourse.

\section{Antisociety language}

Wording - including metaphors - is the normal linguistic way in which humans express meaning. Meaning, however, is not a matter of 'wording' alone. Words and their meaning are part and parcel of a social system. For the purpose of understanding diaphorical wording, language can be said to comprise three linguistic modes of meaning: the ideational, the interpersonal, and the textual (Halliday 1978:8-36, 69, 125-126). ${ }^{11}$ In metaphorical discourse one finds tendencies of 'relexicalisation' and 'overlexicalisation' (Halliday 1978:165-166). The first refers to the practice of using new words to describe a reality not ordinarily referred to by such words. Halliday (1978) puts it this way:

Typically this relexicalization is partial, not total: not all words in the language have their equivalents in the antilanguage ... the principle is that of same grammar, different vocabulary; but different vocabulary only in certain areas, typically those that are central to the activities of the subculture and that set it off most sharply from the established society. (p. 165)

Within institutional Christian religion, an example of relexicalisation is the reference to 'bread' as 'the body of Christ' or to 'wine' as the 'blood of Christ'. Relexicalisation' points to items and objects affecting areas of central concern to the group. 'Overlexicalisation' refers to a situation where there is a multiplicity of words for the central area of concern. This is indicated by a set of words that has the same denotation, but has a different connotation based on the attitude and commitment that the set of words entails in an interpersonal context. The consistent 'relexicalisation' and 'overlexicalisation' - along with a focus on the interpersonal and modal aspect of language - point to what Halliday has referred to as 'antilanguage'. Antilanguage is the language of an 'antisociety', which is:

[a] society that is set up within another society as a conscious alternative to it. It is a mode of resistance, resistance which may take the form either of passive symbiosis or of active hostility and even destruction. (Van Aarde 2009:690; see also Halliday 1978:171)

As a rule, antisocieties have a negative relation to the traditional conventions of society. However, they are not outside society, but in opposition to the established norms

10.Some formulations in this section correspond sometimes ad verbatim to aspects in my article "Foxes' holes and birds' nests" (Mt 8:20): A postcolonial reading for South Africans from the perspective of Matthew's anti-societal language' (Van Aarde 2009).

11.According to Malina and Rohrbaugh (1998:6), the ideational refers to what is being said or described; the interpersonal considers the personal qualities of the communicating partners; and the textual pertains to the linguistic units of meaning at a level higher than the sentence, for example, the cohesion of paragraphs at a level higher than the sentence, for example, the cohesion of paragraphs
into a discourse. Thus, what one says is ideational, with whom one speaks is interpersonal, and how one speaks is textual. 
within society. Antilanguage thus arises when the alternative reality is counter-reality, in opposition to the establishment (see Halliday 1978:171). In other words, an antilanguage is a language derived from, and generated by, an antisocial group. An antisociety group is a social collective that is set up within a larger society as a conscious alternative to it. Antilanguage exists solely in the social context of resocialisation. Like any other language, it is a means of realising meanings from the social system of the society in question. It is a means of expressing perceptions of reality, as interpreted by persons socialised in that social system. Socially, the use of language actively creates and maintains the prevailing interpretations of reality. However, unlike ordinary language, antilanguage creates and expresses an interpretation of reality that is inherently an alternative reality, one that emerges precisely in order to function as an alternative to society at large. In order to understand the phenomenon of antisociety, one has to understand the larger society to which it is opposed. Antisociety makes no sense in the absence of the society against which it stands. Like language itself, antilanguage is the bearer of social reality, but of an alternative social reality that runs counter to the social reality of society at large. Thus, an antilanguage serves to maintain an inner solidarity in the face of pressure from the wider society (from which group members stem, and in which they, to a large extent, are still embedded) (Van Aarde 2009).

Furthermore, for individuals to maintain solidarity with their fellow antisocial members and to avoid falling back into the margins of the groups they have left or from which they have been expelled, some kind of alternative ideology and emotional anchorage in the new collective are necessary. This necessity is best served by demonstrations of mutual care and concern on the part of those in the antisocial group. Language is crucial to the social interpretation of reality and to the socialisation of new members into that social interpretation. So, too, is antilanguage crucial to the social reinterpretation of an alternative reality and to the resocialisation of newcomers into that alternative society.

One could generalise by stating that metaphorical modes of expression are the 'normal' way by means of which antilanguage is articulated. Relating such 'modes of expression' to diaphoric metaphors in the Jesus tradition is to discover a tendency of subversiveness towards language usage which denotes 'reign' and 'empire'. Antisociety diaphoric metaphors in the Jesus tradition oppose structures of domination, control, violence, hierarchy, and patriarchy. However, such a mode of subversive discourse in the 1st century is not restricted to the Jesus tradition or to the New Testament itself - although New Testament authors could borrow from the common language usage found in extra-Christian literature or extra-Jesus sayings. The Stoic notion 'divine economy (dioikēsis tou kosmou) of the basileia', articulated by means of pragmatic parabolic speech (polis displaced by oikodomia), serves as an example of subversive discourse which constitutes an antisocietal alternative to the hegemony of the polis state at the turn of the pre-Christian and Christian eras.

\section{Epictetus, Paul and the Jesus tradition as case studies: Meal, marriage, and pearl}

According to Epictetus, having been liberated from one's given faculties (dunameis) should not result in another 'passivity' that is being subjected to fate of 'whatever happens is God's will' (Epictetus Fragmenta 3). To be set free and not to be a slave anymore, according to Epictetus, is to be destined to make an intentional choice to be thankful for whatever happens 'since it is in accord with our desire'. Conformity to Zeus' will (Epictetus Discourses 1.13.4; Encheiridion 53) causes that:

$[w]$ e will be well-behaved, grateful guests at Zeus' banquet, cheerful, thankful spectators at Zeus' festival, enjoying the show and, when it is over willing leaving, with our hearts still singing Zeus' praises'. (Epictetus Discourses 4.1.104-106) (cf. Sellars 2010:319-320)

This reference to 'leave' implies a decision. Samuel Vollenweider (2013:138) uses the expression: 'die Situation des Abschiednehmens'. What is implied here is the conviction that people as rational beings are able to achieve authenticity by themselves, and when life as a cheerful party becomes bereft of its fortune, the implicature of the metaphor 'meal' is clear, namely that one is destined to make a deliberately rational choice to bring an end to life by means of a suicidal act.

In the time around Nero's reign, when Epictetus, under the mentorship of Musonius Rufus, became a devoted admirer of Socratic ideals (Anthony Long 2002:204), ${ }^{12}$ the 'practice of the Romana mors' (Timothy Hill 2004:27) was ingrained in the moral wisdom of the time. William Oldfather ([1925] 1998) summarises Epictetus's view on the rationale behind the choice for self-killing as follows (citations from Epictetus and emphasis original):

Yet even in his happiness, which we cannot dismiss as a mere pose, there was something wanting. The existence of evil was in one breath denied, and in another presumed by the elaborate preparations that one must make to withstand it. 'And having done all, to stand?' No, even after having done all, 'the house might get too longer to endure; the ominous phrase, 'the door is open,' or its equivalent, the final recourse of suicide, recurs at intervals through [Epictetus's] pages like a tolling bell. And beyond? Nothing. Nothing to fear indeed; 'the dewdrop sinks into the shining sea.' 'When [Zeus] provides the necessities no longer, He sounds the recall: He opens the door and says, 'Go.' Where? To nothing you need fear, but back to that from which you came, to what is friendly and akin to you, to the physical elements' ([Discourses] III.13.14). But at the same time there is nothing to hope for. (pp. $x x v-x x v)$

From Paul's perspective, this would be self-righteousness par excellence.

Paul shares Epictetus's common wisdom concerning the 'divine economy', namely that all humankind is bound to the

12.With regard to suicide, Long $(2002: 204)$ puts the resemblance as follows: 'As so often, Epictetus blends his Stoicism with an unmistakable allusion to Socrates. While granting the conditional propriety of suicide, he also mimics Socrates' While granting the conditional propriety of suicide, he also mimics Socrates'
famous quotation of the saying that no one should leave the guardhouse until God has given the signal.' 
norms of nature (nomos and phusis), that all human beings are bound to take care of each other, including specifically those traditionally marginalised and cast out, that all human beings are called to obey God, and that all humankind is destined to die. According to Paul, the condition to be bound to nature is to be chained - like a slave - to sin (hamartia), destined for corruption and ultimately death. However, Paul differs from Epictetus. Despite the many similarities between middle-Platonic Stoicism and Pauline thinking, according to Paul, bound to nature does not imply the propriety of suicide. Instead, a free rational choice for 'suicide' is displaced by Paul by antisociety - that is 'anti-Stoic' - language of 'participatory death'. Self-killing became sharing the death of Christ Jesus, but also the sharing of his resurrection from the death ( $\mathrm{Rm}$ 6:4). Although Paul uses ambiguous language in this regard and although he sometimes sees an ana-logia between a bodily death (crucifixion) and a bodily resurrection, in essence, his 'anti-Stoic' language, similar to Epictetus amongst others, is expressed through parabolic discourse.

Similar to the reliance of the freed slave Epictetus on his teacher Musonius Rufus, and again, the student Arrianus's reliance on Epictetus as teacher, the faith of the freed slave Paul is modelled after Christ Jesus who is crucified as well as resurrected. For Paul, faith in God and the righteousness of God - a two-in-one concept - creates, diaphorically seen from an antisociety language perspective, a context comparable to a 'meal'. This 'meal' refers metaphysically to a celebratory interactional participatory event with transformative situational and ethical effect. In a shocking way a believing participant of the 'meal' celebrates the realisation of the 'divine economy' by remembering the death and resurrection of Christ Jesus (cf. 1 Cor 11:23-26).

Paul's 'anti-Stoic' language implies a disagreement regarding the necessity of suicide in light of real or anticipated unbearable afflictions. However, the implicature of the metaphor used by Paul is in essence different from some other (earlier and later) Christian theologians who operated epistemologically and linguistically with a dualistic Platonic mindset (e.g. Thomas Aquinas). It is also different from modern moral philosophers' (e.g. Immanuel Kant) view on suicide. Both Aquinas and Kant argued strongly against the antisocietal act of self-killing. The first wants to save the 'immortal soul' of the believer who destroys both body and soul through an act of suicide. The latter advocates the virtues of courage (Mut), strength of soul (Seelenstärke), and the recognition (kennen) of one's own personality as subject of morality, so that one can conquer the fear for fustigatio (fatigue on account of being hit by fists), flagellatio (physical exhaustion on account of scourging by whips), and verbaratio (emotional disintegration caused by verbal abuse). These were the steps in Roman trials following a verdict of guilt (cf. Neyrey 2007:302). This mastigō (suffering) was a real threat which slaves, criminals and foreigners as defeated political subjects had to fear. It consists of physical and emotional affliction through external and internal hostility. Seen together with internal affliction caused by illness, physical disability and other imbalances, hardship and misfortune are 'nature's way' of saying that the 'meal' is over.

However, both these theologians (e.g. Aquinas) and moral philosophers (e.g. Kant) misunderstand Stoic determinism (see David James 1999:40-58). The Stoic rationale for the 'ultimate justification of man's freedom' (Seneca, in John Rist 1969:233) to choose for suicide, according to Seneca (cited in Rist 1969:233), 'perhaps even as the only genuinely

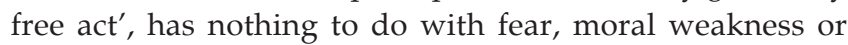
cowardice. It also does not imply a negligence of one's moral duties. On the contrary, it emphasises humankind's freedom of hardship and represents a unity of phusis in both the individual and in humankind collectively. Shadi Bartsch (2009) puts it as follows:

$[W]$ e all know that the Stoic psyche is not binary... and that the model of the body as a container for the soul has no place in orthodox Stoicism, in which the soul itself is material and, as pneuma, is distributed evenly throughout the body. (p. 188)

Similar to Epictetus with regard to his students (Herbert Braun 1962:159-167; contra Wolfgang Schrage 1964:125-154), Paul also calls Christ-followers to gain knowledge about 'the rules' (nomos) of the nature of things and behave according to that place in nature (1 Cor 7:20). ${ }^{13}$ Yet, it is a vocation with a transformative twist in ethos, because it does not comply with a conformation with the world, but with the 'mindset' of God and of Christ Jesus (see Rm 12:2; cf. Van Aarde in press).

He or she who has become a believer (Christ-follower) stands free against the world and is free of the world (Gert Pelser 1996:717). The rationale of this radical, although ambiguous, freedom is that the relationship between the Christian and the kosmos has been 'crucified' (Hans-Dieter Betz 1979:319). Death sets free, and a widow can verify the statability of this diaphorical assertible with regard to marriage (cf. Rm 7:1-6). It is a freedom against and of the kosmos, not because of an eschatologically Naherwartung, but because of the here-and-now both 'dying with' and 'living with' Christ Jesus. ${ }^{14}$ Such an ethos does not imply an ascetic or mystic escapism, but rather a responsibility towards the dogmata of the world, for example to marry, and to buy and sell. The telos of marriage, however, is not procreation alone, if at all. One has the freedom to refrain from marriage or cohabitation, and another person can choose otherwise (see 1 Cor 7:7-24; esp. 7:29-32). It remains, however, from a moral perspective, good if one can be free of Angst (1 Cor 7:32a) (cf. Balch 1983:429-439). Why? Because the kairos of God has 'contractions' (sun-estalmenos estin) (1 Cor 7:29) and the 'schemes' of this world died away (schemma tou kosmou paragei) (1 Cor 31b) - not 'is passing away' as the Revised Standard Version ([1991] 1998:452) translates the present

13.See Paul's use of calling (klësis) in 1 Corinthians $7: 20$.

14.I do not read 1 Corinthians 7:29 (ho kairos sunestalmenos estin - ISV: 'the appointed time has grown very short') and 1 Corinthians 7:31 (paragei gar to schēma tou kosmou - ISV: '[flor the form of this world is passing away) as references to an imminent eschatological expectation. The Greek should rather be understood as: 'The time (ho kairos) has contractions (sunestalmenos).' The second phrase should be understood as: 'The schema of the world died away/passed away (paragei). 
indicative of paragō as if it expresses a current and durative verbal action, but 'passed away' in the sense of 'expired' ${ }^{15}$ The kosmos became an adiaforon in the sense that the world ended (Pelser 1996:726).

Paul sees marriage, business and possessions as elements of a transient kosmos. A Christ-follower who dies with Christ lives entweltlicht, free of the world although in the world. The concept 'contraction' (sunestalmenos estin) fits in the schema of procreation and the maintenances of the kosmos. It, however, also implies a 'metaphorical twist' because it also refers to a (re)birth. For Paul, a 'walking continuation' (peripatein) is more important than a 'static remaining' (menein). Everything which is created will corrupt and die away anyway. The Christ-follower who is crucified with Christ is also resurrected with Christ.

While the antisociety language in John's Gospel (see Bruce Malina \& Richard Rohrbaugh 1998:1-16) focuses on 'born to die' (Jn 19:37), in Epictetus's dissertations on 'die to end hope and enter nothingness' (Discourses III.13.14), Paul, on the other hand, in his antisociety language use, focuses on 'die to live' (2 Cor 5:14-15). What came to life because of the 'contraction of time' is the 'dying of the world'.

The implicature of the parabolic discourse of the 'divine economy' is to 'live as if not ['als ob nicht' - Vollenweider 2013:149) you die' (in Greek, hos mē: in 1 Cor 7:29, 30, 31) (cf. Samuel Vollenwider 2013:144). The pragmatic dimension of this diaphorical assertible - within the protecting framework (kalupsis) of God's will - consists of a life-giving transformative interactional event: the displacement of the 'authentic I' with the 'authentic other', being aware of otherness by applying the law of love as the ground rule in the divine economy of the basileia - irrespective of whether in marriage or in management, according to both Paul and Epictetus (Balch 1983:429); female and male are 'similar' and each other's equal (Balch 1983:439), the same for being a slave, or a 'lame old man', or an exposed child. ${ }^{16}$ This radical love was, is and remains the essence of the divine economy of the basileia.

It has become clear that the dynamics of the economy of the kingdom of God need not focus on the parables of Jesus alone (see Katrina Dronsch [2008] above). However, it is true that these dynamics probably are more apparent and comprehensible in the parable discourse of the Jesus tradition than in Stoic philosophy. For this purpose one can reflect on the three parables that conclude the parabolic discourse in Matthew 13: the Hidden treasure; the Pearl; Worthless fish. Matthew 13 forms the Zentrum of Matthew's macrostructure (Ulrich Luz 1985:37), a discourse consisting of seven parables on God's kingdom with the last three as Sondergut material (Mt 13:44-52). The discourse ends with Jesus asking, 'Do you

15.The $A$ ktionsart of the present indicative in this paragraph is contextually determined by the opening phrase in which time (kairos) is the explicit subject in a sentence grafted in a perfect participle periphrastic grammatical form (sunestalmenos estin). Trafted in a perfect participle periphrastic grammatical form (s
The Actionsart of the perfect is to express a factual condition.

16.Epictetus remained unmarried until old age 'when he adopted an infant who would otherwise have been exposed to death and after years of celibacy took wife (or live-in female servant) to support the child' (Anthony Long 2002:11). understand them all?' His students answer 'Yes'. The reader has to read between the lines to understand the nature of the 'divine economy'.

The basileia is like a treasure worth seeking wholeheartedly. When one finds it, one throws away (in Greek, ekballō) all that is useless in the dioikēsis theia - similar to what fishers do with useless fish. The treasure is worth so much that it could be compared with that one particular pearl for which one searches an entire lifetime. When one finds it, one should be like the master of the house (oikonomos) who takes from the treasure chest in the oikodomia all that is old and new and throws it out (cf. Peter Phillips 2008:3-24 and Elaine Wainwright 2011:375-388 who interpret the Greek ekballo in Mt 13:48 and Mt 13:52 in correspondence with each other). These are extreme and subversive instructions. The Matthean Jesus corresponds here to the Stoic philosopy of 'die Situation des Abschiednehmens' (Samuel Vollenweider 2013) and the Pauline theology of participatory death as a metaphorical self-killing.

Integrity requires that word and deed should correlate; and by doing so you would cherish a pearl worth more than a million dollars (see Klyne Snodgrass 2008:248). Indeed, to die is to live in abundance. It is a transformative act based on the epistemological, ethical and cosmological freedom that is part of the divine economy of the basileia!

\section{Acknowledgements}

In dedication to friend and Dean, Johan Buitendag, who coined the notion 'ecodomy as a house with many rooms - fullness in abundance'; an oikodomia, an okeiōsis, an intellectual and moral edifice in which we experience affinity and affection.

\section{References}

Aristoteles, [1957] 1964, 'Politica', in W.D. Ross (ed.), Aristotelis politica, 1252a1-1342b-34, Clarendon Press, Oxford.

Aristotle [1953] 1973, Poetics, ed. \& transl. W.H. Fyfe, Heinemann, London. (The Loeb Classical Library).

Aristotle, [1967] 1970, Poetics, transl. F.F. Else, University of Michigan Press, Ann Arbor, $\mathrm{Ml}$.

Aristotle 2007, The Poetics, Chapter 21, 1457b1-30, transl. I. Bywater, in J. Garret, 'Aristotle on metaphor: Excerpts from Poetics and Rhetoric', viewed 17 March 2014, from http://people.wku.edu/jan.garrett/401s07/arismeta.htm

Auer, P., 1996, 'From context to contextualization', Links \& Letters 3, 18-19.

Balch, D.L., 1983, '1 Cor 7:32-35 and Stoic debates about marriage, anxiety, and distraction', Journal of Biblical Literature 102(3), 429-439. 'http://dx.doi. org/10.2307/3261016

Baldry, H.C., 1965, The unity of mankind in Greek thought, Cambridge University Press, Cambridge. http://dx.doi.org/10.1017/CBO9780511735851

Bartsch, S., 2009, 'Senecan metaphor and Stoic self-instruction', in S. Bartsch \& D. Wray (eds.), Seneca and the self, pp. 188-217, Cambridge University Press, Cambridge.

Beardsley, M.C., 1958, Aesthetics: Problems in the philosophy of criticism, Harcourt, Brace \& Co, New York, NY.

Betti, E., [1962] 1990, 'Hermeneutics as the general methodology of the Geisteswissenschaften', transl. J. Bleicher, in G. Ormiston \& A.D. Schrift (eds.), The hermeneutic tradition from Ast to Ricoeur, pp. 177-188, State University of New York Press, Albany, NY.

Betz, H-D., 1979, Galatians, Fortress Press, Philadelphia, PA. (Hermeneia).

Black, M., 1981, 'Metaphor', in M. Johnson, Philosophical perspectives on metaphor, pp. 63-82, University of Minnesota Press, Minneapolis, MN.

Blank, D. \& Atherton, C., 2003, 'The Stoic contribution to traditional grammar', in B. Inwood (ed.), The Cambridge Companion to the Stoics, pp. 310-327, Cambridge University Press, Cambridge. http://dx.doi.org/10.1017/CCOL052177005X.013 
Bobzien, S., 2003, 'Stoic logic', in B. Inwood (ed.), The Cambridge Companion to the Stoics, pp, 85-123, Cambridge University Press, Cambridge.http://dx.doi. the Stoics, pp. 85-123, Cambridge
org/10.1017/CCOL052177005X.005

Braun, H., 1962, 'Die Indifferenz gegenüber der Welt bei Paulus und bei Epiktet', in $\mathrm{H}$. Braun, Gesammelte Studien zum neuen Testament und seiner Umwelt, pp. 159-167, Mohr (Paul Siebeck), Tübingen.

Brown, R.H., 1976, 'Social theory as metaphor: On the logic of discovery for the social sciences of conduct', Theory and Society 3(2), 169-197. http://dx.doi. org/10.1007/BF00161676

Bublitz, W. \& Norrick, N.R., 2011, 'Introduction: The burgeoning field of pragmatics', in W. Bublitz \& N.R. Norrick (eds.), Foundations of pragmatics, pp. 1-20, Walter de Gruyter, Berlin. (Handbook of Pragmatics, 1).

Crossan, J.D., 1992, s.v. 'Parable', in D.N. Freedman (ed.), The Anchor Bible Dictionary, vol. 5, pp. 148-150, Doubleday, New York, NY

Crossan, J.D., 2012, The power of parable: How fiction by Jesus became fiction about Jesus, HarperOne, New York, NY.

Décarie, V., [1975] [2003] 2004, 'Between rhetoric and poetics: Aristotle', in P. Ricoeur (ed.), The rule of metaphor: The creation of meaning in language, pp. 8-48, Taylor \& Francis e-Library, Routledge \& Kegan Paul, London.

Derrida, J., 1978, 'The retrait of metaphor', Enclitic 2, 5-33.

Derrida, J., 1982a, 'Différance', in Margins of philosophy, transl. A. Bass, pp. 1-29, Chicago University Press, Chicago, IL.

Derrida, J., [1972] 1982b, 'White mythology: Metaphor in the text of philosophy', in J. Derrida, Margins of philosophy, transl. A. Bass, pp. 207-272, Chicago University Press, Chicago, IL.

Diogenes Laertius [1853], 2008, 'Diogenes Laertius', in C.D. Yonge \& K. Seddon, The lives and opinions of eminent philosophers, rev. version of Book Seven, pp. 112-118 [Cleanthes], pp. 119-121 [Spaerus], Lulu Press, Hertfordshire, viewed 11 April 2014, from http://www.lulu.com

Dronsch, K., 2008, 'Auf der Suche nach der Bedeutung der Gleichnisse Semiotische Aspekten', in R. Zimmermann \& G. Kern (eds.), 2008, Hermeneutik der Gleichnisse Jesu, pp. 570-587, Mohr Siebeck, Tübingen. (Wissenschaftliche Untersuchungen zum Neuen Testament, 231).

Epictetus, [1916], Dissertationem Epicteteum sive ab Arriano sive ab aliis digestarum fragmenta, pp. 455-460, 462-475, H. Schenkl (ed.), Teubner Verlag, Leipzig.

Epictetus, [1925] 1998, Discourses, Books 3-4, Fragments, The encheiridion, transl. W.A. Oldfather, pp. 479-537, Harvard University Press, Cambridge. (Loeb Classical Library).

Freud, S., [1919] 1970, 'Das Unheimliche', in S. Freud, Studienausgabe IV, 7th edn., pp. 241-275, Fischer, Frankfurt am Main.

Funk, R.W., 1966, Language, hermeneutic, and word of God: The problem of language in the New Testament and contemporary theology, Harper \& Row Publishers, New York, NY.

Gordon, P., 1990, 'The enigma of Aristotelian metaphor: A deconstructive analysis', Metaphor and Symbolic Activity 5(2), 83-90. http://dx.doi.org/10.1207/ s15327868ms0502_2

Grondin, J., 1994, Introduction to philosophical hermeneutics, foreword by HansGeorg Gadamer, transl. J. Weinsheimer, Yale University Press, New Haven, CT. (Yale Studies in Hermeneutics).

Groß, S., 2005, 'Das Unheimliche': Sigmund Freud, TPS 'Medien des Schauderns', Peter Matussek, WS 2005/2006, 15.11.2005, viewed 29 March 2014, from http://www.peter-matussek.de/Leh/S_32_Material/S_32_M_04/04_freud_Gross

Halliday, M.A.K., 1978, Language as social semiotic: The social interpretation of language and meaning, Edward Arnold, London.

Hands, R.A., 1968, Charities and social aid in Greece and Rome, Thames and Hudson, London.

Hedrick, C.H., 2004, Many things in parables: Jesus and his modern critics, Westminste John Knox Press, Louisville, KY.

Herder, J.G., [2006] 2009, 'Introduction', in G. Moore (ed.), Johann Gottfried Herder: Selected writings on aesthetics, transl. G. Moore, pp. 1-30, Princeton University Press, Princeton, NJ.

Hill, T.D., 2004, Ambitiosa mors: Suicide and the self in Roman thought and literature, Routledge, New York, NY.

Huang, Y., 2011, 'Types of inference: Entailment, presupposition, and implicature', in W. Bublitz \& N.R. Norrick (eds.), Foundations of pragmatics, pp. 397-424, Walter de Gruyter, Berlin. (Handbook of Pragmatics, 1).

Hübler, A., 2011, 'Metapragmatics', in W. Bublitz \& N.R. Norrick (eds.), Foundations of pragmatics, pp. 107-136, Walter de Gruyter, Berlin. (Handbook of Pragmatics, 1).

James, D.N., 1999, 'Suicide and Stoic ethics in the Doctrine of virtue', Kant-Studien 90, 40-58. http://dx.doi.org/10.1515/kant.1998.90.1.40

Johnson, M. (ed.) 1981, 'Metaphor in the philosophical tradition', in M. Johnson (ed.) Philosophical perspectives on metaphor, pp. 3-47, University of Minnesota Press, Minneapolis, MN.

Joy, M., 1988, 'Derrida and Ricoeur: A case of mistaken identity (and difference), The Journal of Religion 68(4), 508-526. http://dx.doi.org/10.1086/487924

Jülicher, A., 1888, 'Das Wesen der Gleichnisreden Jesus', in A. Jülicher, Die Gleichnisreden Jesu, pp. 24-121, Akademische Verlagsbuchhandlung J.C.B. Mohr (Paul Siebeck), Freiburg.

Kaplan, D. M., 2003, Ricoeur's critical theory, State University of New York (SUNY) Press, New York, NY.
King, C., [2010] 2011, Musonius Rufus: Lectures and sayings, transl. C. King with preface by W.B. Irvine, Lulu Press, Raleigh, NC.

Kompa, N. \& Meggle, G., 2011, 'Pragmatics in modern philosophy of language', in W. Bublitz \& N.R. Norrick (eds.), Foundations of pragmatics, pp. 203-228, Walter de Gruyter, Berlin. (Handbook of Pragmatics, vol. 1).

Konstan, D., 2010, 'Are fellow citizens friends? Aristotle versus Cicero on Philia, Amicitia, and social solidarity', in R. Rosen \& I. Sluiter (eds.), Valuing others in classical antiquity, pp. 233-248, Brill, Leiden. http://dx.doi.org/10.1163/ ej.9789004189218.i-476.76

Lakoff, G. \& Johnson, M., 1980, Metaphors to live by, Chicago University Press, Chicago.

Liddell, H.G. \& R. Scott (eds.), [1843] 1961, A Greek-English lexicon, 9th edn. Clarendon, Oxford

Long, A.A., 2002, Epictetus: A Stoic and Socratic guide to life, Oxford University Press, Oxford.

Luz, U., 1985, Das Evangelium nach Matthäus, 1. Teilbd.: Mt 1-7, Benziger, Zürich (Evangelisch-Katolischer Kommentar zum Neuen Testament). http://dx.doi. org/10.1093/0199245568.001.0001

Malina, B.J. \& Rohrbaugh, R. L., 1998, Social-science commentary on the Gospel of John, Fortress Press, Minneapolis, MN.

Malitz, J., 1988, 'Philosophie und Politik im frühen Prizipat', in P. Schmidt \& P. Wülfing (eds.), Antikes Denken: Moderne Beiträge zu den antiken Grundlagen unseres Denkens, pp. 151-179, Carl Winter Verlag, Heidelberg. (Gymnasium Beihefte, 9).

McGinn, M., 1989, Sense and certainty: A dissolution of scepticism, Basil Blackwell, London.

McFague, S., 1982, Metaphorical theology: Models of God in religious language, Fortress Press, Philadelphia, PA.

Millar, F., 1965, 'Epictetus and the imperial court', Journal of Roman Studies 55, 141-148. http://dx.doi.org/10.2307/297436

Neyrey, J.H., 2007, The Gospel of John, Cambridge University Press, Cambridge. (The New Cambridge Bible Commentary).

Oldfather, W.A., [1925] 1998, In Epictetus: The discourses as reported by Arrian, Books I-II, transl. W.A. Oldfather, Harvard University Press, Cambridge. (Loeb Classical Library).

Pelser, G.M.M., 1996, 'Die verhouding kerk en wêreld/kultuur in die lig van die Pauliniese "asof nie" (hōs mē)', HTS Teologiese Studies/HTS Theological Studies 52(4), 715-733. http://dx.doi.org/10.4102/hts.v52i4.1557

Phillips, P., 2008, 'Casting out the treasure: A new reading of Matthew 13:52', Journal for the Study of the New Testament 31, 3-24. http://dx.doi. org/10.1177/0142064X08095176

Reed, J.T., 1997, 'Discourse analysis', in S. E. Porter (ed.), A handbook to the exegesis of the New Testament, pp. 189-218, Brill, Leiden.

Reinstorf, D. \& Van Aarde, A.G., 1998, 'Jesus' kingdom parables as metaphorical stories: A challenge to a conventional worldview', HTS Teologiese Studies/Theological Studies 54(3/4), 603-622. http://dx.doi.org/10.4102/hts.v54i3/4.1436

Revised Standard Version (RSV), [1991] 1998, in E. Nestle, (B. Aland \& K. Aland, [eds.]), Greek-English New Testament, 8th rev. edn., Novum Testamentum Graeca, 27th edn., Deutsche Bibelgesellschaft, Stuttgart.

Richards, I.A. [1924] 1928, The principles of literary criticism, with rev. preface, Kegan Paul, New York, NY.

Richards, I.A., [1936] 1981, 'The philosophy of rhetoric', in M. Johnson (ed.), Philosophical perspectives on metaphor, pp. 48-62, University of Minnesota Press, Minneapolis, MN.

Ricoeur, P., 1974, 'Metaphor and the main problem of hermeneutics', New Literary History 6(1), 95-110, John Hopkins University Press, viewed 25 March 2014, from http://www.jstor.org/discover/10.2307/468343?uid=2\&uid=4\&s id=21104633862763

Ricoeur, P., 1975, 'Biblical hermeneutics', Semeia 4, 29-145.

Ricoeur, P., 1981, 'The metaphorical process as cognition, imagination, and feeling', in M. Johnson (ed.), Philosophical perspectives on metaphor, pp. 228-247, University of Minnesota Press, Minneapolis, MN

Ricoeur, P., [1986] 2004, The rule of metaphor: The creation of meaning in language, Routledge, London.

Rist, J.M., 1969, Stoic philosophy, Cambridge University Press, Cambridge.

Roskam, G., 2005, On the path to virtue: The Stoic doctrine of moral progress and its reception in (middle-)Platonism, Peeters/Leuven University Press, Leuven.

Schleiermacher, F.D.E., [1830] [1928] 1976, The Christian faith, 2nd edn., transl. H.R. Mackintosh \& J.S. Stewart, T \& T Clark, Edinburgh.

Schrage, W., 1964, 'Die Stellung zur der Welt bei Paulus, Epiktet und der Apokalyptik: Ein Beitrag zu 1 Kor 7.29-31', Zeitschrift für Theologie und Kirche 61, 125-154.

Sellars, J., 2003, The art of living: The Stoics on the nature and function of philosophy, Ashgate Publishing, Burlington, VT.

Sellars, J., 2010, 'Epictetus', in A. Grafton, G.W. Most \& S. Settis (eds.), The classical tradition, pp. 319-320, The Belknap Press of Harvard University Press, Cambridge.

Shaw. B.D., 1985, 'The divine economy: Stoicism as ideology', Latomus 44(1), 16-54, Societe d'Etudes Latines Bruzelles, viewed 31 March 2014, from http://www.jstor. org/discover/10.2307/41543542?uid=2\&uid=4\&sid=21104633862763

Snodgrass, K.R., 2008, Stories of intent: A comprehensive guide to the parables of Jesus, Eerdmans, Grand Rapids, MI. 
Stadter, P.A., 1967, 'Flavius Arrianus: The new Xenophon', University of North Carolina, Chapel Hill, viewed 06 April 2014, from http://grbs.library.duke.edu/ article/viewFile/11241/4199

Troeltsch, E., [1912] 1992, The social teaching of the Christian churches, vol. 1, transl. O. Wyon, foreword by J.L. Adams, Westminster John Knox Press, Louisville, KY.

Van Aarde, A.G., 1994, 'The historical-critical classification of Jesus' parables and the metaphoric narration of the wedding feast in Matthew 22:1-14', in Van Aarde, A.G., God-with-us: The dominant perspective in Matthew's story, and other essays, pp. 229-247, Gutenberg, Pretoria, (HTS Theological Studies, suppl., 5).

Van Aarde, A.G., 2009, “'Foxes' holes and birds' nests" (Mt 8:20): A postcolonial reading for South Africans from the perspective of Matthew's anti-societal language', HTS Teologiese Studies/Theological Studies 65(1), Art. \#318, 10 pages. http://dx.doi.org/10.4102/hts.v65i1.318

Van Aarde, A.G., 2013, 'Little faith as an alternating state of religious consciousness: A pragmatic-empirical perspective on Matthew's portrayal of Jesus' disciples', Studia Historiae Ecclesiasticae 39, 187-212.

Van Aarde, A.G., (in press), 'Faith as an exceptional religious state of consciousness: A pragmatic-linguistic reading of Romans 12', paper presented at the North-West University (Potchefstroom) in memoriam of Abraham Malherbe, 01 August, 2013 LITVerlag, München.
Vollenweider, S., 2013, 'Lebenskunst als Gottesdienst: Epiktets Theologie und ihr Verhältnis zum Neuen Testament', in S. Vollenweider, M. Baumbach \& E. Ebel (eds.), Epiktet: Was ist wahre Freiheit?: Diatribe IV 1, pp. 119-162, Mohr Siebeck, Tübingen. (Scripta antiquitatis posterioris ad ethicam religionemque pertinentia, 22).

Wainwright, E., 2011, 'Beyond the crossroads: Reading Matthew 13:52 ecologically into the twenty first Century', in D.P. Senior (ed.), The Gospel of Matthew at the crossroads of early Christianity, pp. 375-388, Peeters, Leuven. (Bibliotheca Ephemeridum Theologarum Lovaniensium CCXLIII).

Wells, R., [1954] 1961, 'Meaning and use', in S. Saporta (ed.), Psycholinguistics: A book of readings, pp. 269-283, Holt, Rinehart \& Winston, New York, NY.

Wheelwright, P., [1962] 1973, Metaphor and reality, Indiana University Press, Bloomington, IN.

Wistrand, E., 1979, 'The Stoic opposition to the principate', Studii Clasice 18, 93-101.

Wittgenstein, L., [1918] [1922] 2010, Tractatus Logico-Philosophicus, with an introduction by B. Russell, Harcourt, Brace Company, New York, NY, available as e-book under 'Project Gutenberg's Tractatus Logico-Philosophicus', transl. C.K. Ogden, viewed 14 July 2013, from http://www.gutenberg.org/ebooks/5740

Zeller, E., 1909, Die Philosophie der Griechen in ihrer geschichtlichen Entwicklung, T. 3, 1: Die nacharistotelische Philosophie, pp. 765-761, Fues (Reisland), Leipzig. 